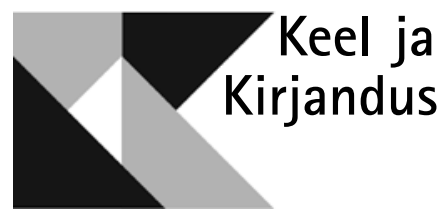

\title{
JÄTKUSUUTLIK KEELEPOLIITIKA: KAS JA KUIDAS?
}

\author{
MAARJA SIINER, TRIIN VIHALEMM
}

\section{Sissejuhatus}

Täesolevat artiklit ajendas meid kirjutama mure eesti keele jätkusuutlikkuse pärast XXI sajandil ühiskonna kommunikatsioonisüsteemi

1 osana. Eesti Vabariigi põhiseaduse preambul sätestab, et Eesti keelepoliitika juhtivaks printsiibiks on eesti rahvuse, keele ja kultuuri jätkusuutlikkus. Seatud eesmärk annab võimalusi erinevateks tõlgendusteks. Praegune Eesti keelepoliitiline diskursus, mis avaneb seadustekstides, arenguprogrammides ning ajakirjanduses, käsitleb eesti keelt sageli inimesest eraldiseisva nähtusena. Keele arengu visioonides on sisuliselt kõrvale jäetud nii inimesed, kelle jaoks eesti keel on teine keel või võõrkeel, kui ka need, kelle jaoks eesti keel on emakeel. Leiame, et tänapäeva maailmas, kus inimesed liiguvad palju ringi ja majanduslik-tehnoloogiline areng soosib senisest veelgi enam lingua franca'de kasutamist nii töö- kui ka erasfääris, peaks väikeriigi keelepoliitika kasutama vähem lineaarseid keelekasutajate käitumist mõjutavaid võtteid ning püüdlema pigem keele erinevate kasutuskeskkondade kujundamise poole. 


\section{Kas liigne hoolitsus võib ka halba teha?}

Tulenevalt Eesti riigi ajaloolisest ja demograafilisest eripärast on keelepoliitika ülesanne taasiseseisvunud Eestis olnud viimastel aastakümnetel taaskehtestada eesti keel igakülgselt funktsioneeriva riigikeelena, kaitstes seda eeskätt vene keele võimu ning mõju eest (vt nt Hogan-Brun jt 2009). Tulevikus nähakse ohuna inglise keele mõjuvõimu kasvu ning eestlaste kasutatavate suhtlusvahendite ja -keskkondade mitmekesistumist, mis muudab keelekasutuse kontrolli raskeks. ${ }^{1}$ Nende keele normkuju ohustavate faktorite teadvustamises pole iseenesest midagi taunitavat. Probleemiks on, et keelenormi kaitse kõrval puudub järjekindel ja süsteemne poliitika, mis püriks esmalt kasutajate eluilma mõistma ja alles seejärel muutma keelekasutuse viise tänases ja tuleviku Eesti ühiskonnas. Eestis on keelepoliitika uurimisel ja tulemuslikkuse hindamisel vaadeldud keelepoliitikat ühesuunalise, ülevalt alla toimiva riigipoolse kontrollimehhanismina, mille subjektid on institutsioonid (nt haridusasutused), keelegrupid (nt venekeelsed, murrete rääkijad) ja üksikisikud (muulased või eestlased). Keelekaitse ülesande lahtimõtestamine eeskätt keelekasutust tõkestava ja kontrolliva süsteemi loomisena marginaliseerib tahtlikult või tahtmatult küsimused, mis puudutavad keelekasutuse sotsiaalset konteksti ehk olusid, milles tänapäeva eesti keele kasutajad, õppijad ja õpetajad elavad ning toimetavad.

Kui näiteks USA-s või Taanis määrab keelepoliitika suuna poliitiline päevakord ja parteide võimuvõitlus (Phillipson 2001; Ricento 2005; Siiner 2010), siis Eesti keelepoliitilises diskursuses domineerib parteideülene kitsalt keeleteaduslik keelekäsitlus (keel on kirjakeele norm) ja sellest tulenevalt normeeriv ja kaitsev-kontrolliv paradigma. Keelenormi kaitse seotus eesti identiteedi ja rahvuse säilimisega (EKAS: 6) annab purismile etnilise alatooni. See seos muudab normatiivsuse paradigma, mis tegelikult on olemas ka nõrga või õhukese keelepoliitikaga riikides (Spolsky 2004), Eestis eriti võimsaks, kuna võimaldab alternatiivseid keelepoliitilisi diskursusi süüdistada riigi julgeoleku ohustamises (Koreinik 2011: 52), raskendades näiteks poliitilist või parteipõhist debatti keele teemal. Meedia vahendatud avalikes aruteludes troonib idealiseeritud keelekasutaja konstruktsioon (kelleks on toimetaja või keeleteadlane), tavakasutajat hoiatatakse ning manitsetakse, mõnikord arvatakse ka diskursiivsete võtetega arutelust välja. ${ }^{2}$

Selle, kas eesti keel muutuvas maailmas elava keelena püsima jääb, määravad paljuski just keele tavakasutajad. Eesti keelekorralduses tegeldakse küll tõhusalt sellega, et tagada keele kasutatavus: arendatakse oskussõnavara, luuakse keeleabivahendeid ja -tehnoloogiaid jms, kuid ei tegelda süsteemselt ning järjekindlalt tegelikku keelekasutust mõjutavate ideoloogiliste ja majanduslike teguritega. Seda, et kaalukauss on tugevasti keele kui süsteemi, mitte keelekasutaja poole kaldu, on möönnud näiteks eesti keele õpetamise

${ }^{1}$ Näiteks 2004. aasta keelepoliitika raamdokumendis (EKAS) ja selle järelstrateegiat kujundavas Eesti keele arengukavas 2011-2017 (EKA) on strateegilise põhieesmärgina selgelt esile toodud kasvav vajadus tagada eesti keele (normi) kaitse laiemalt (EKA: 3-9), kusjuures ohustavate teguritena on määratletud eestlaste endi keelekasutusvajaduste ja -tavade muutumine, suurenenud keeleliselt kontrollimatu tekstiloome (EKAS: 11).

${ }^{2}$ Näiteks leidis Kadri Koreinik lõunaeesti keele tulevikku käsitlevate meediatekstide süvaanalüüsil, et mitteakadeemiliselt ehk n-ö (liht)keelekasutajatelt on võetud keele tuleviku küsimustes agentsus (Koreinik 2011: 39). 
uurijad. Emakeeleõpet ja eesti keele õpet teise keelena nähakse ainena, kus peamiselt omandatakse teoreetilisi teadmisi keele grammatikast, jättes tihtilugu unarusse praktilise keeleoskuse ehk eneseväljenduse arendamise nii kõnes kui ka kirjas (Brock 2012; Pool, Tenjes 2011: 352). Tiina Brock, kes on uurinud keeleõppe didaktikat, nendib, et emakeeleõpe on elust kaugenenud ja muutnud aine koolis üheks ebapopulaarsemaks (Brock 2012: 5). Tekkinud liikumine „Uus emakeeleõpetus” (Brock 2012: 21) ja õpikud, mis käsitlevad keeleteemat laiemas kontekstis (nt Ehala jt 2012), annavad märku sellest, et ka praktikud on probleemi tunnetanud.

Hiljuti üliõpilaste hulgas läbiviidud eesti keele oskuse uuring näitas, et valdav enamik testi sooritanutest on õigekeelsuse omandanud vähemalt rahuldaval määral, samas on noortel raskusi just funktsionaalse keelepädevusega ehk suhtluspädevusega (Ehala jt 2010: 65). Eesti keele arendamise strateegia rakendusdokumendi koostajad nendivad, et „võrreldes 2003. aastaga on noorte hinnangud eesti keele kui tõhusa kommunikatsioonivahendi osas muutunud pessimistlikumaks ning seda vaatamata asjaolule, et objektiivselt on eesti keel 2010. aastal oluliselt paremini arendatud kui kaheksa aasta eest" (EKASE: 4). Keele tõhusust ei saa aga reguleerida otse, keeldude ja käskudega ülevalt poolt, vaid seda kujundab inimkäitumine ehk keele kasutaja vajaduste muutumine (Fishman jt 1991: 28). Igas suhtlusolukorras toimub niikuinii teatav keelesüsteemi isereguleerumine, nagu on nentinud akadeemik Uno Mereste (Hausenberg 2009: 250). Eesti noorte pessimism eesti keele tõhususe suhtes ning kasvav lõhe keelekasutuse ja keelenormi vahel on signaal, mida kõik keele tuleviku pärast muretsejad peaksid tõsiselt võtma ning püüdma üheskoos mõtestada, usaldades kitsalt keeleteadusliku lähenemise kõrval ka interdistsiplinaarseid uuringuid. Oluline on vaadelda keelt keelekasutaja ja kasutuse kontekstis ning keelepoliitika prioriteete muutuvas ajas ja ruumis ümber seada.

Käesolev artikkel keskendub mõningatele keelepoliitika paradigmaatilistele rõhuasetustele, mille üle teistes riikides sisuliselt vaieldakse, kuid mis Eestis on takerdunud ideoloogiliste deklaratsioonide lävepaku taha. Toome oma väidete illustreerimiseks mõningad näited muulasi puudutava keelepoliitika kohta, sest oleme just seda valdkonda põhjalikumalt uurinud. Eesti keele kehtestamine siin elavate vähemuste teise keelena ei ole kitsalt vene õppekeelega koolide probleem, vaid puudutab laiemalt kogu ühiskonda, näiteks regionaalarengut, tööturgu, töötust ning sellega seotud sotsiaalkaitse süsteemi ehk teisisõnu maksuraha kasutust. Samuti mõjutavad selles valdkonnas tehtu või tegematajätmised kaudselt ka eesti keele õpet emakeelena. Eestis on ihaldusväärse seisundi prototüübiks sageli Põhjamaades kasutatavad mudelid. Ka käesolevas artiklis toome eesti keele teise keelena omandamise ja kasutamise valdkonda analüüsides paralleelselt näiteid selle kohta, kuidas sarnast olukorda Taanis reguleeritakse. Teises kultuuris ja poliitilises kontekstis kasutatavaid lahendusi ei saa loomulikult muutumatul kujul üle võtta, kuid nende kõrvutamine võimaldab vaadelda meil toimuvat uues valguses. 


\section{Kas käsitleda keeleoskust kui seisundit või kui protsessi?}

Keelepoliitika prioriteedid ja kaudselt ka edukuse kriteeriumid on seotud sellega, mida keele all mõistetakse (Schiffmann 1996). Keelekasutuse uurijad rõhutavad keele protsessilaadset loomust (Jørgensen 2010). James W. Tollefson on väitnud, et keelepoliitika käsitlus, mis keskendub vaid lihtsalt mõõdetavatele näitajatele, nt eksamiga mõõdetavale keeleoskusele, avaldatud sõnaraamatute arvule jne, on liiga kitsas ja tehnokraatlik. Tollefson rõhutab vajadust vaadelda keelepoliitikat kui protsessi, mitte kui valmisprodukti, sest muutuvate oludega kaasnevad muutused keelekasutajate käitumises ja vajadustes ning seega ka vajadus keelepoliitikat uues olukorras korrigeerida (Tollefson 2006). Keelt omandatakse kõige paremini selle kasutuskeskkonnas, keelelise sotsialiseerumise kaudu, mitte ainult koolipingis. On isegi väidetud, et liigne tähelepanu keelele mõjub keelekasutusele/suhtlusele pärssivalt (Zinkernagel 1992: 6; seda keelekasutuse psühholoogilist omapära on käsitlenud ka Hjelmslev 2012).

Eestis avaldub seisundi mõõtmisele keskenduv lähenemine esmajoones eesti keele kui teise keele kehtestamis- ning sellega tihedasti seonduvas lõimumispoliitikas. Muu emakeelega inimeste lõimumisprotsesside edukuse mõõtmine on seni olnud väga instrumentaalne ja testidega mõõdetava keeleoskuse keskne, kuigi võrreldes esimese programmiga „Integratsioon Eesti ühiskonnas 2001-2007” on uues programmis „Eesti lõimumiskava 2008-2013” rohkem tähelepanu pööratud ka kodanikukasvatusele ning sotsiaal-majanduslikule lõimumisele. Viimase integratsiooni monitooringu (EIM) andmed näitavad, et ei omandatud keeletaseme tunnistus ega isegi eesti keele kasutamine suhtluses eestlastega ei pruugi kaasa tuua kuuluvustunnet Eesti ühiskonda ja ka vastupidi. On olemas ka vähese keeleoskusega, kuid tugeva kodanikuidentiteediga Eesti riigi suhtes lojaalsete inimeste rühm ehk nn venekeelsed Eesti patrioodid. Samas on tekkinud Eesti riigi suhtes kriitiline rühm (valdavalt noori) inimesi, kes oskavad suhteliselt hästi eesti keelt, kuid on nõrga või olematu kodanikuidentiteediga. ${ }^{3}$ Kriitilisi eesti keele oskajaid iseloomustab aktiivne eestikeelse meedia jälgimine ja ka osalemine väljaannetega seotud virtuaalsetes suhtluskeskkondades.

Seda rühma eristab keele omandamise ja kodanikuidentiteedi dimensioonis n-ö harmooniliselt lõimunud rühmast just lähedaste kontaktide puudumine eestlastega, kuigi nad elavad valdavalt Tallinnas, mitte Ida-Virumaal. Harmooniliselt lõimunud venekeelsetel noortel on sagedamini eestlastest sõpru-tuttavaid, võrreldes üksnes keeleliselt lõimunutega. Viimased väidavad aga keskmisest sagedamini, et on kogenud rahvuslikku või keelelist diskrimineerimist ja konflikte just meedia vahendusel (EIM: 202, 243). Seega on eesti keele oskus avanud neile eestikeelsed virtuaalsed keskkonnad, kus nad kogevad muu hulgas ka rahvuslikku vaenu ja sallimatust. Samas puuduvad inimesed, kes aitaks kultuurikonteksti mõtestada. See toob ilmekalt esile, et kitsalt keeleoskuse omandamise motiveerimine ei pruugi anda soovitud tulemusi. Keeleomandamisprotsess peaks olema läbi põimitud teiste ühiskonnas osalemiseks vajalike teadmiste ning oskuste omandamisega. Siiani on väljaspool klassi ja koolitundi toimuvaid tegevusi käsitletud kui toredaid, kuid mitte

\footnotetext{
${ }^{3}$ Ülalmainitud rühmad moodustavad ligikaudu vastavalt $13 \%$ ning $16 \%$ kõigist $15-$ 74-aastastest Eesti elanikest, kelle emakeel ei ole eesti keel. Allikas: EIM.
} 
tingimata vajalikke integratsioonipoliitika meetmeid, millest võib ressursside nappuses ka loobuda. Poliitika ülesanne peaks aga olema just suhtluskeskkondade pikaajaline ning süsteemne kujundamine. Praegu läheb oluline ressurss vene õppekeelega koolide õpetajate keeleoskuse kontrollimisele, mitte nende sotsiaalsele lõimimisele, edendades õpetajate ja õpilaste omavahelist koolivälist suhtlust: õpetajate ja õpilaste vahetust, eesti ja vene õppekeelega koolide õpetajate ühiskoolitusi, tugivõrgustikke jms (EIM: 233-234).

Keelepoliitika, mis keskendub liigselt keeleoskuse kontrollile, kõrgendab näiteks veelgi muukeelse taustaga inimestele kehtivaid ligipääsutõkkeid tööturu kõrgematele positsioonidele. Kujuneb välja tõrjumispraktika, mis toimib nii otseselt, keeletaseme määratluste alusel, kui sageli ka kaudselt, teatud normide ja stereotüüpide konstrueerimise näol, mis mõjutavad töötajate värbamist ja edutamist. Eestis on tööturule pürgijatele esitatavad keeleoskusnõuded viimase 10-15 aastaga pigem karmistunud (Lindemann 2011: 297).

Selle muutuse taga ei ole mitte niivõrd juriidilised kui ideoloogilised põhjused: teatud sotsiaalsed normid ja stereotüübid, mida tööandjad teadlikult või alateadlikult järgivad. Enda väitel Eesti tööandjad inimese etnilise tausta suhtes ise eelarvamuslikud ei ole, kuid nad kaaluvad valiku turvalisust näiteks ettevõtte töökollektiivi ja klientide võimalikke reaktsioone ennustades (MISA 2009). Piisavalt „turvaline” on praegu valida vaid väga hästi eesti keelt kirjutada oskavad kandidaadid (Lindemann 2011: 297), kes enamasti ka suulises suhtlemises tugevad on. Seega vajavad tööturu kõrgematele positsioonidele pürgijad kõrgtaseme keeleoskuse arendamise (keelekorrektsiooni) võimalusi ning vastavaid tugistruktuure, sisuliselt mentorisüsteemi. Selleks on vaja ette valmistada õpetajaid, vastavaid vabahariduslikke süsteeme (nt keeleklubid, keelementorid töökohtadel vms), riik võiks initsieerida ning toetada neid kindla suunitlusega, et turul oleks vajadustele vastav pakkumine (EIM: 238).

Suletud ring tekib ka tööturu alumistel astmetel nende vene taustaga noorte seas, kes siirduvad oma kehva keeleoskuse ja vähese keelelise enesekindlusega põhikoolist kutsekooli või otse tööturule. Inimesi, kes pole suutnud eesti keelt enne tööturule sisenemist piisaval tasemel omandada, ähvardab oht sattuda veelgi suuremasse sotsiaalsesse isolatsiooni, mis takistab ka keeleoskuse paranemist. Ja Eestis on muukeelsed nii geograafiliselt kui ka sotsiaalselt isoleeritumad kui Lätis (Vihalemm, Siiner 2011: 120): suur osa elab kontsentreeritult Kirde-Eestis, kus eestlasi on vähe. ${ }^{4}$ See vähendab omakorda võimalusi eesti keelt praktiseerida. Inimesed ei leia tööd või töötavad ükskeelsetes töökohtades, kus neil puudub otsene kontakt (eestikeelsete) klientidega ning nende töökaaslased on samuti vähese või olematu eesti keele oskusega inimesed. Keeleõppe tõhustamine põhi- ja kutsekoolis võib asja küll parandada, ent selle mõju avaldub siis, kui noortel on võimalus eesti keelt kuskil kasutada. Läti kogemus näitas, et majanduskasvu ajal rakendatud ajutine mitteformaalne töölevõtu tingimuste leevendamine just keelenõuete osas hoopis laiendas riigikeele kasutajate ringi, sest tööturule pääsenutel oli parem võimalus läti keele oskust suhtluses täiendada (Hazans 2010).

Eestis võiks näiteks kõigis kutseõppeasutustes praktiliste tööoskuste omandamine käia käsikäes eesti keele õppega, selmet avada erikeelseid õpperühmi.

${ }^{4}$ Mihails Hazansi arvutuste järgi oli aastatel 2000-2004 etniline palgalõhe Lätis peaaegu kaks korda väiksem kui Eestis, samuti töötute osakaalu vahe enamuse ja vähemuse seas (Hazans 2010). 
Muidu püsib nõiaring: selleks et leida keeleoskuse parandamise võimalusi, pead sa juba keelt oskama. Samal ajal on struktuursed tingimused (keeleõpetuse tase koolides, keele koolivälise praktiseerimise võimalused) selle oskuseni jõudmiseks piirkondade lõikes ebaühtlaselt jaotunud, nagu ka keele omandamist toetav sotsiaalne ning majanduslik kapital (suhtlusvõrgustikud, täiendava keeleõppe võimalused jm). Teatud piirini või/ja teatud sotsiaalsete rühmade puhul toimib sisenemisbarjääride seadmine keele omandamise motivaatorina, kuid paljudel juhtudel ei kutsu selline ühekülgne regulatsioon harjumuslikust keelekeskkonnast üldse väljuma. Pikemas ajaperspektiivis takistab see keele kasutusruumi ja kasutajaskonna kasvu, rääkimata tööturul rakendatud maksumaksjate arvu kasvust.

Erinevalt Eestist nähakse Taanis täiskasvanud muukeelse keelelise ja kultuurilise õppimise kohana eelkõige töökohta. See toetub arusaamale, et keeleõpe pole kitsalt keele kui reeglite süsteemi omandamine koolipingis, vaid toimub igapäevase suhtluse käigus kodupiirkonnas, tööl ja vaba aega veetes (Borberg 2002; Pedersen 2002). Taanis ja Põhjamaades üldiselt soodustatakse sisserännanute võimalikult kiiret tööturule sisenemist, kuna lisaks oskuskeele ja praktiliste oskuste omandamisele ametikohal on oluline ka töökultuuri ja ühiskonnas kehtivate kirjutamata seaduste omandamine. Sellest filosoofiast lähtudes on täiskasvanud sisserännanute keeleõpe tihedalt seotud nende ametialase järelõppe ja tööturule lõimumisega, mis saadab selge signaali, et keeleõppe eesmärk on iseseisvalt toimetulemine endale ise elatist teenides (Husted jt 2010). Taanis on olemas töötute järelõppe ja tööle taasrakendamise seadus (BLAB), mis näeb ette võimaluse keeleoskust (kohaliku omavalitsuse toetusel) ka töö ja väljaõppe/järelõppe käigus täiendada ning mis eeldab nii riiklike kui ka eraettevõtete aktiivset partnerlust selles protsessis, näiteks ka keelementori kasutamist töökohal.

\section{Kes on keelepoliitika otsustaja ja kes on täideviija?}

Eespool kirjeldatud käsitlust keelest kui protsessist kasutab etnograafilisi meetodeid viljelev keelepoliitika uurimise suund, mis tekkis vajadusest paremini mõista keelepoliitika mikro- ja makrotasandi vahelisi seoseid ehk seda, kas ja kuidas on keelekasutust võimalik tõhusamalt suunata (Hornberger, Johnson 2007). Peale makrotasandi (riik) on keelepoliitikas olemas ka meso(nt kohalikud omavalitsused, ettevõtted ja institutsioonid) ning mikrotasand (keelekasutaja) (Van der Aa, Blommaert 2011). Vaidehi Ramanathani sõnul võimaldab keelepoliitika vaatlemine eri tasanditel ehk kihilisena uurida nii eri kihtide vahelisi seoseid kui ka seda, kuidas igas kihis leiab aset poliitika kontekstuaalne, sihtrühma- ja valdkonnapõhine tõlgendamine ning kuidas sellised kõrvalekalded poliitikute seatud ametlikest eesmärkidest pole mitte nurjumised, vaid hädavajalikud „vabaruumid”, milles sündivad tõlgendused võimaldavad ametliku ja - nagu Ramanathan ütleb - neljakandilise poliitika ümbermõtestamist ja kohaldamist (2005: 98-99). Keelepoliitika vaatlemine protsessina, mis toimub mitmel eri tasandil, lubab näha keelepoliitiliste agentidena mitte ainult poliitikuid, vaid ka praktikuid nt koolides, ettevõtetes või kohaliku omavalitsuse tasandil. 
Rebecca Freeman (2004) on rõhutanud, et „vabaruumid”, mis võimaldavad ametliku poliitika ja individuaalsete/institutsionaalsete tõlgenduste põrkumist, on just hariduses hädavajalikud uute ja kohalikus kontekstis toimivate lahenduste ja sünteesi tekkeks. Kui ametlik poliitika võib valitsuse või ideoloogiate vahetudes muutuda suhteliselt kiiresti, on inimeste keelepraktikad, hoiakud ja tavad aeglasemad muutuma. Keelepoliitika etnograafiline uurimissuund (Hornberger, Johnson 2007) rõhutab seega vajadust vaadelda keelepoliitikat mitte kui ühesuunalist, ülevalt alla toimuvat protsessi, vaid kui mõlemasuunalist ja mitmel eri tasandil (nt perekonnas, koolis, töökohal) toimuvaid katseid keelelise mitmekesisusega toime tulla (Cooper 1989: 45). Selline lähenemine laiendab tunduvalt keelepoliitika mõistet, vaadeldes keelepoliitika osana ka rohujuure tasandil tekkinud kohalikke initsiatiive ning ametliku poliitika vastase protestina sündinud „mitteametlikku poliitikat”. Keelepoliitika mõiste laiendamine võimaldab uurida keele kasutaja, õppija ja õpetaja rolli keelepoliitika kujunemisel ja kujundamisel mitte kui segavat, vaid kui paratamatut ja hädavajalikku.

Eestis on keelepoliitika selline tõlgendamine harjumatu. Kuigi meil on keeleõppe ja -oskusega seonduvad probleemid selgelt seotud teatud piirkondade ja institutsioonidega, on lahenduste pakkuja rollis olnud pikka aega riik, kas siis usaldamatusest kohalike omavalitsuste vastu või ka kohalike tegutsejate harjumuste, oskuste ja ressursside puuduse tõttu. Kuna otsustus- ja algatusõigus on pikka aega olnud riigil, puudub sisuliselt avalik diskussioon näiteks teemal, kuidas kõige paremini tagada venekeelse õppekeelega koolide üleminek eesti õppekeelele ning milliseid sotsiaalseid tugivõrgustikke õpilased, koolid ja õpetajad tegelikult vajavad. Ja õpetajatel puudub julgus anda tagasisidet kartuses, et neid tembeldatakse ametliku poliitika saboteerijateks (Vihalemm jt 2011). Samas oleks õpetajate ja teiste praktikute tagasiside toimivate lahenduste leidmiseks hindamatu väärtusega ja vajadust selle järele on ka tunnistatud näiteks praegu kehtivas lõimumiskavas. Kokkuvõttes ongi võimalused leida kohalikele probleemidele kohalikke lahendusi väga piiratud ning niigi kasinaid riiklikke ressursse koormab kohustus pidevalt kontrollida avaliku keelekasutuse õigsust ja keeleoskuse taset.

Taanis puudub ametlik keeleseadus, sest puudub poliitiline tahe ja ka tajutav vajadus taani keele positsiooni seadusega kaitsta. Sellest tuleneb riigi suhteliselt tagasihoidlik roll enamikus keelepoliitika valdkondades (Siiner 2010). Avalikus poliitilises diskursuses on levinud hoiak, et keelekasutuse ametlik reguleerimine piirab sõnavabadust, mistõttu keelekasutuse kontrolli ja reguleerimist peetakse nii ebademokraatlikuks kui ka praktiliselt raskesti teostatavaks. Taani keelt ja selle arengut uuriva ning õigekeelsussõnaraamatut väljaandva institutsiooni Dansk Sprognævn (Taani Keelenõukogu) roll on peaasjalikult nõustada ja soovitusi jagada, asutusel puudub kontrolli funktsioon. Et riiklikul tasandil taani keele sümboolset staatust rõhutav diskursus puudub, ei tajuta keelekasutust madalamatel tasanditel reguleerivaid otsuseid assimileerivate või diskrimineerivatena, kuigi mõned uurijad on seda väitnud (Holmen, Jørgensen 2010).

Taanis arvestatakse, kuidas ressursse võimalikult tulemuslikult kasutada ja kuidas hädavajalikke otsuseid serveerida nii, et need muutuksid vastuvõetavaks. Taani keele kui teise keele õppega seotud probleemidele püütakse leida kohalikke ja kontekstuaalseid lahendusi, nii et konkreetne institutsioon 
või omavalitsus on lahenduse pakkuja, mitte passiivse täideviija rollis. Näiteks on muukeelsete laste taani keele oskuse hindamine, tugiõppe pakkumine ja kontroll seadusega delegeeritud kohalikele omavalitsustele ja institutsioonidele. Sama kehtib täiskasvanud hilisimmigrantide puhul, kellele pakuvad keeleõpet kohaliku omavalitsuse haldusalas tegutsevate tööhõive ja integratsiooni osakonna alluvuses töötavad keeltekoolid. Taani keelepoliitika peamine eripära võrreldes meie omaga ongi keelepoliitika madalamate tasandite, nt kohalike omavalitsuste keskne roll keelepoliitika rakendamisel, aga ka toimivate mudelite leidmisel.

Näiteks tekkis Kopenhaageni mudel (Kofoed jt 2010) siis, kui linnavalitsus pidi lahendama olukorra, kus teatud ringkonnakoolidesse koondus suur hulk muukeelseid lapsi, kuna need koolid asusid piirkondades, kus asus palju sotsiaalseid üüripindu. Et keeleline sotsialiseerumine on sellistes tingimustes raskendatud, pakkus linnavalitsus lahendusena muukeelsete laste jaotamist naaberkoolide vahel (lapsed toodi ja viidi bussiga linna teise kooli), kus sellist probleemi ei olnud. Mudeli toimimisest annab tunnistust tõik, et nüüdseks on see seadusemuudatusena põhikooliseadusesse sisse kirjutatud. Teine näide kohaliku lahenduse leidmisest on Taani riiklikes ja eraülikoolides vastu võetud regulatsioonid, mille eesmärk on tagada ülikoolis nii teadustöötajate hea inglise keele oskus kui ka taani keele positsiooni säilimine toimiva teaduskeelena. Mitmed Taani ettevõttedki on sarnaselt ülikoolidega juurutanud keelepoliitikat, mille eesmärk on tagada asutuse töötajate heatasemeline keelekasutus või reguleerida erinevate keelte kasutust ettevõttes ja selle harudes. Need nime poolest keelepoliitikad on üldiselt ka laiemad kommunikatsioonistrateegiad, pakkudes kontrolli asemel tugimeetmeid (keeleõpet, -nõustamist, esinemisoskuse arendamist, netipõhiseid terminoloogiasõnaraamatuid jms) ning sidudes keelekasutuse ettevõtte brändi ja sisemise kultuuriga (nt kohalike keelte kasutamise toetamine tütarettevõtetes vms).

Uuringud näitavad, et sellised kohalikud lahendused toimivad kõige paremini olukorras, kus madalama taseme keelepoliitilistel agentidel, näiteks omavalitsustel, on olemas nii otsustusõigus kui ka materiaalsed vahendid probleemi tuvastamiseks ja lahendamiseks (Siiner 2012). Kui riigi keskne roll keelepoliitika otsustaja ja täideviijana kujuneb liiga ulatuslikuks (nagu Eestis), tekib paratamatult nii rahaliste kui ka ajaliste ressursside, oskuste ning legitimatsiooni nappus keele omandamist pärssivate probleemide tuvastamiseks, toimivate lahenduste leidmiseks ja tugistruktuuride käivitamiseks. Riigipoolsete, ressursipuudusel tekkinud tegematajätmiste eest „vastutavad” aga keelekasutajad ja -õppijad, sest nendelt nõuab riik või töökoht tulemusi. Aktiivsemad üksikindiviidid võivad näidata lahenduse leidmiseks initsiatiivi, kuid need lahendused tihti pigem süvendavad kui lahendavad probleemi. Seda ebakõla analüüsime lähemalt järgmises alapeatükis.

\section{Keeleõppija vajadused erinevates elufaasides}

Eespool mainitud etnograafilisi meetmeid viljelevast keelepoliitika uurimissuunast inspireerituna analüüsib üks autoritest, Maarja Siiner, oma doktoritöös keelepoliitiliste meetmete tõhusust lähtuvalt sellest, millises elufaasis regulatsioonid keelekasutaja ja õppija ellu sekkuvad (Siiner 2012). Et keelel 
on inimese eri elufaasides erinev psühholoogiline funktsioon, on tulemuslikum keeleõppe ja -kasutuse reguleerimine varases eas, koolieelsetes lasteasutustes ja põhikoolis, sest just selles vanuses toimub keeleline sotsialiseerumine (Choudhry 2009). Taanis näiteks on sisse viidud muudatused koolieelsete lasteasutuste ja põhikooliseaduses, mis reguleerivad muukeelsete laste taani keele õpet ja nende taani keele oskusele esitatavaid nõudmisi juba alates kolmandast eluaastast, kaasates sellesse ka nende perekondi.

Nii taani- kui ka muukeelse taustaga koolieelikute keeleoskuse kontroll ja vajadusel tugiõpe on tõhusad vahendid keeleprobleemide varajasel tuvastamisel, vältimaks neist tulenevaid hilisemaid raskusi koolis hakkamasaamisel, sest lasteaiad, põhikoolid ja gümnaasiumid on Taanis valdavalt taanikeelsed. Sarnast kontrolli ja tugiõpet jätkatakse ka põhikoolis. Hiljem see kontroll kaob ja asendub ülikooli tasandil ja tööturul pakutavate tugistruktuuridega. Seega võib väita, et Taanis on ametlik, vähemusi assimileeriv keelepoliitika siiski olemas, kuigi varjatud kujul: näiteks on kaotatud riigi toetus immigrantide laste emakeeleõppele (Holmen, Jørgensen 2010). Mainitud lahendusi on peaasjalikult esitatud praktiliste lahendustena, kuna nende ideoloogiline ja poliitiline alatoon jääb avaliku keeleideoloogilise diskursuse puudumise tõttu varju.

Eestis on olukord vastupidine: nõudmisi esitatakse ja kontrolli teostatakse alles gümnaasiumi tasemel ja täiskasvanutele. Kuigi koolieelsete lasteasutuste seadusesse on sisse kirjutatud eesti keele õppe kohustus muu õppekeelega lasteasutustes ( $\$ 8)$, ei kata selle olemasolu sisulisi vajadusi. Esiteks ei puuduta see lasteaias mittekäivaid lapsi. Teiseks on segane, millise jätkuhariduse jaoks lapsi lasteaias ette valmistada: kas laps läheb pärast lasteaeda eesti- või venekeelse õppega põhikooli? Vene õppekeelega põhikooli ettevalmistuse ning olulises osas eestikeelse aineõppega gümnaasiumi nõuete vahel on samuti suur lõhe. Selline süsteem ei taga, et muukeelne laps suudaks gümnaasiumis jälgida ainetundi eesti keeles. Need venekeelse põhikooli lõpetanud noored, kes gümnaasiumi ei jõuagi, jäävad keelelise abi osas enamasti „eikellegimaale”, sest kutseõppeasutuste eesti keele õpe põimitult praktilise kutseõppega on alles lapsekingades. Praktilistele probleemidele lahenduste leidmist ei soosi ka keelepoliitika üleideologiseeritus, mis näiteks takistab vene koolide tulevi$\mathrm{ku}$ küsimuse laiemat ja avatud arutelu ühiskonnas.

Praegu on tekkinud suur „sotsiaalne tellimus” eestikeelse alushariduse osas: ülekaalukalt eelistavad vene ja muu emakeelega vastajad eestikeelse õppe algust juba lasteaias (EIM: 28). Keelepõhiselt eraldatud lasteaedade pooldajate osakaal kahaneb, $65 \%$ muukeelsetest inimestest pooldaks ühist eestikeelset lasteaeda, kus on teistest rahvustest laste jaoks nende emakeelt valdavad abikasvatajad (EIM: 7). Praegune alushariduse süsteem pole selle tellimuse täitmiseks ilmselt valmis. Kas nüüd hakatakse taas tõkestama sissepääsu keelekeskkonda, s.t vanemad, kes tahavad panna oma lapsi eestikeelsetesse lasteaedadesse, saadetakse tagasi venekeelsetesse lasteaedadesse? Mahasurumise asemel oleks oluline sellist üksikisiku initsiatiivi aktsepteerida kui vox populi’t, mis annab märku mittetoimivatest või puuduvatest poliitilistest lahendustest.

Vaja oleks ka laiemaid, kontseptuaalseid hariduspoliitilisi muutusi, eeskätt (abi)õpetajate ettevalmistuse osas. Need on kahtlemata ressursimahukad, kuid pikemas perspektiivis aitaksid raha säästa (täiskasvanute keele- 
kontroll, koolitus, ümberõpe, töötute sotsiaalkaitse jne). Suhteliselt suur osa vene kodukeelega peresid on juba praegu pannud oma lapse eesti õppekeelega kooli. ${ }^{5}$ Kuna muukeelsete laste tuleku eesti koolidesse on otsustanud vanemad (ja mitte nt kohalik omavalitsus nagu Taanis), ei kaasne sellega automaatselt arutelusid teemal, kuidas õpetada emakeeletundides muukeelsele lapsele eesti keelt. Kuidas õpetada ajalugu? Lahenduse peavad leidma õpetajad ja lapsevanemad. See tähendab, et laste tuleviku väljavaated sõltuvad paljuski elurajoonist ning vanemate sotsiaalsest lõimitusest ja toimetulekuvõimest. See aga soosib omakorda getostumist, sotsiaalsete probleemide süvenemist teatud piirkondades ning sotsiaalse ja keelelise tõrjutuse kandumist järgnevale põlvkonnale.

\section{Lõpetuseks}

Praeguses keelepoliitikas on suhteliselt vähe läbi mõeldud keele roll keelekasutajate elus ja ühiskonnas laiemalt ning on läbi analüüsimata keeleoskuse alusel ehitatavate barjääride sotsiaalsed ja majanduslikud tagajärjed. Eesti keelepoliitilises diskursuses domineerib endiselt üsna kitsas, võiks öelda, et tehnokraatlik visioon keelest kui reeglite süsteemist ning sellele rajatud arusaam, et kodanike keelelist käitumist saab suunata kontrolli ja karistusmeetmete kaudu. Keele kaitsmise vajadus tuleneb tunnetatud ohustatusest, mis ei pruugi aga tegelikkusega kooskõlas olla (Heller, Duchêne 2007). Eesti keelepoliitika analüüsides on selle praeguse mudeli (ja ohustatuse diskursuse) kujunemisel viidatud lähiminevikust tulenevatele paratamatustele. Toimunud protsesse tagasi kerida ei saa, seega me ei tea ega saagi kunagi teada, kas mingi muu poliitika võinuks olla tõhusam tagamaks paremat keeleõpet ja muukeelsete rakendamist tööturul. On aga üsna selge, et praeguse keelepoliitika mõju ulatub tulevikku ja seetõttu on vajalik süsteemsem ning interdistsiplinaarsem poliitika planeerimine. Jätkusuutlik keelepoliitika peaks tegelema keele kasutatavuse arendamise kõrval ka selle kasutamise tingimuste ja võimaluste loomise ehk keele sotsiaalsete kasutuskeskkondade kujundamisega, kaugemas perspektiivis ka sotsiaalse võrdsuse ja sidususe tagamisega.

Pakkusime välja mõningad elemendid, mida peaks jätkusuutliku keelepoliitika kujundamisel arvesse võtma. Esmalt on oluline, et keelepoliitika aluseks on arusaam keele protsessilaadsest loomusest ning kasutaja osalusest selles protsessis. Dünaamilisest keele mõistest lähtuvalt on oluline vaadelda ka riigi keelepoliitikat kui dünaamilist tööriista, mis peab muutuma koos keelekasutajate ja neid ümbritseva ühiskonna ning laiema majanduslik-poliitilise konteksti muutumisega. Nende vajaduste tuvastamisel ja probleemidele lahenduse otsimisel on oluline kaasata peale riigi ka teisi selle protsessiga seotud toimijaid alates kohalikest omavalitsustest kuni ettevõteteni. Võrreldes keeleseaduse kahe esimese, 1989. ja 1993. aasta versiooniga, on viimases, 2011. aasta versioonis keeleseaduse objektiks muukeelsete kõrval selgemalt tõusnud ka need, kellele eesti keel on emakeel. Nii eestikeelseid inimesi kui ka neid, kes kasutavad seda teise keelena, on hakatud vaatlema ühe keeleruumi

${ }^{5}$ Põhikooliastmes osales eestikeelses õppes 2009/2010. õppeaastal 5902 õpilast, kelle emakeel ei ole eesti keel - ligi $22 \%$ kõigist põhikooliõppureist, kelle emakeel ei ole eesti keel, ning 6,5\% kõigist eesti õppekeeles õppijatest (EKA: 16). 
ja ühiskonna osana, keda mõjutavad samad tegurid: suhtlusvõimaluste mitmekesistumine ja kirjaliku keelekasutuse raskem kontrollitavus. Samal ajal on endiselt vajaka arusaamisest, kuidas eri keelegrupid üksteist ja kogu keeleruumi oma käitumisega ja toimetulekuga mõjutavad.

Artiklis analüüsisime Eesti praeguse keelepoliitika ning ametliku keeleideoloogia vastavust jätkusuutlikkuse kriteeriumidele, pidades silmas, kuidas soodustada eesti keele kui teise keele omandamist ja selle kasutamist koolis ning tööturul. Keelepoliitika eesmärki tagada valdavalt (heas) eesti keeles suhtlemine kogu Eesti territooriumil ei ole võimalik saavutada peamiselt nõudes ja kontrollides keeleoskuse taset. Toimivate lahenduste leidmiseks on vaja keelepoliitilise olukorra kompleksset analüüsi, võttes aluseks keelekasutajate vajadused vastavalt nende elufaasile ja ressurssidele ning hinnates kriitiliselt ka riigi suutlikkust kontrollida ja pakkuda kohapeal toimivaid lahendusi. Näiteks oleks vaja täiskasvanute keeleõpe tihedamalt siduda tööturule siirdumise ja järelõppega. See eeldab peale riigi ka muude keelepoliitiliste toimijate, näiteks kohalike omavalitsuste, töökohtade ja haridusasutuste kaasamist.

Eesti keele (tugi)õpe koolieelsete lasteasutuste ja põhikooli tasandil sõltub aga vene õppekeelega koolide saatusest ehk sellest, milleks last ette valmistatakse: kas vaid vene õppekeelega koolis õppimiseks või aktiivseks Eesti ühiskonna kodanikuks sirgumiseks. Selle küsimuse lahendamiseks oleks vaja laiemaid hariduspoliitilisi ja regionaalpoliitilisi otsuseid. Praegu kehtib olukord, kus vähese eesti keele oskusega muukeelset noort „karistatakse” täiskasvanuks saades (nt tööturul kehtivate keeletõkete või teatud keeletaseme nõuete kaudu) sisuliselt riigi tegemata töö eest eelkooli ja põhikooli tasandil. Sellises olukorras sõltub noore hakkamasaamine elukohast ja vanemate ettevõtlikkusest ja nii süvendab selline mudel veelgi sotsiaalset ebavõrdsust Eesti ühiskonnas. Praegune keele normikohasuse ja staatuse ületähtsustamine on takistanud nägemast keelelise lõimumise probleemi komplekssust ja selle sotsiaalseid tagamaid ning võib-olla on just seetõttu loobutud lahenduste otsimisel eri valdkondade teadlaste laialdasemast kaasamisest.

Artikli valmimist on toetanud Eesti Teadusfondi grant $n r 8347$ ja Euroopa Liit Euroopa Regionaalarengu Fondi kaudu (Kultuuriteooria tippkeskus).

\section{Allikad ja kirjandus}

$\mathrm{BLAB}=$ Bekendtgørelse af lov om en aktiv beskæftigelsesindsats, https://www. retsinformation.dk/Forms/r0710.aspx?id=136419

B o r b e r g, Karin Ryø 2002. Integration handler om at klare sig selv. - Magasinet Lederne, $\mathrm{nr} 4$.

B r o c k, Tiina 2012. Uus emakeeleõpe gümnaasiumis kahe õppeelemendi näitel. Magistritöö. Tartu Ülikool.

C h o u d h ry, Sujit 2009. Managing linguistic nationalism through constitutional design: Lessons from South-Asia. - International Journal of Constitutional Law, kd 7, nr 4, lk 577-618.

C o o p er, Robert 1989. Language Planning and Social Change. Cambridge: Cambridge University Press. 
E h a l a, Martin, K e r g e, Krista, L e p a j õ e, Kersti, S õ r m u s, Kadri 2010. Kõrgkoolide üliõpilaste eesti keele oskuse tase. Uuringukokkuvõte. Tartu Ülikool.

E h a l a, Martin, H a b i c h t, Külli, K e h a y o v, Petar, Z a b r o d s k aj a, Anastassia 2012. Keel ja ühiskond. Õpik gümnaasiumile. [Tallinn:] Künnimees.

$\mathrm{EIM}=$ Eesti ühiskonna integratsiooni monitooring 2011 (http://www.kul.ee/webeditor/files/integratsioon/Integratsiooni_monitooring_2011.pdf).

EKA = Eesti keele arengukava 2011-2017. Haridus- ja Teadusministeerium, 2011.

EKAS = Eesti keele arengu strateegia 2004-2010. Haridus- ja Teadusministeerium, 2004.

EKASE = Eesti keele arendamise strateegia 2004-2010 elluviimine. Haridus- ja Teadusministeerium, 2011.

F i s h m a n, Joshua, S o l a n o, Frank R., M c C o n n e 1l, Grant D. 1991. A methodological check of three cross-polity studies on linguistic homogeneity/heterogenity. - Languages in School and Society: Policy and Pedagogy. Toim M. McGroarty, C. J. Faltis. Berlin-New York: Mouton de Gruyter, lk 21-29.

F r e e m a n, Rebecca 2004. Building on Community Bilingualism. Philadelphia: Caslon Publishing.

$\mathrm{H}$ a z a n s, Mihails 2010. Ethnic Minorities in the Latvian Labour market, 19972009: Outcomes, Integration Drivers and barriers. - How Integrated is Latvian Society? Toim N. Muižnieks. Riga: University of Latvia Press, lk 125-158.

H a u s e n b e rg, Anu-Reet 2009. Kuhu lähed, eesti keel? Sõnavara muutumine jätkub. - Keel ja Kirjandus, nr 4, lk 249-259.

Heller, Monica, D u chêne, Alexandre 2007. Discourses of endangerment: Sociolinguistics, globalization and social order. - Discourses of Endangerment. Toim A. Duchêne, M. Heller. London-New York: Continuum, lk 1-13.

$\mathrm{H} \mathrm{j} \mathrm{e} \mathrm{l} \mathrm{m} \mathrm{s} \mathrm{l} \mathrm{e} \mathrm{v,} \mathrm{Louis} \mathrm{2012.} \mathrm{Sissejuhatus} \mathrm{keeleteooria} \mathrm{alustesse.} \mathrm{Tallinn:} \mathrm{Eesti} \mathrm{Kee-}$ le Sihtasutus.

H o g a n - B r u n, Gabrielle, O z o li n s, Ulmans, R a m o n i e n e, Meilute, R a n n u t, Mart 2009. Language Politics and Practices in the Baltic States. Tallinn: Tallinn University Press.

Holmen, Anne, Jørgen se n, Jens Normann 2010. Skærpede holdninger til sproglig mangfoldighed i Danmark. - Sprogs status i Danmark 2021. Toim J. N. Jørgensen, A. Holmen. Københavnerstudier i tosprogethed, kd 58, lk 87-105.

H o r n b e r g e r, Nancy, J o h n s o n, David Cassels 2007. Slicing the Onion Ethnographically: Layers and Spaces in Multilingual Language Education Policy and Practice. - TESOL Quarterly, kd 41, nr 3, lk 509-532.

H u s ted, Leif, B onfils, Inge Storgaard, La u ritze n, Helle Bendix, Ni e l s e n, Solveig Baltzer 2010. Indvandrerkvinder i danskuddannelsen (http://www. akf.dk/udgivelser/2010/pdf/indvandrerkvinder_i_danskuddannelsen.pdf/).

J ø r g e n s e n, Jens Normann 2010. Languaging. Nine years of polylingual development of young Turkish-Danish grade school students. 2 vols. (Copenhagen Studies in Bilingualism, K15-K16.) University of Copenhagen.

Kofoed, Jette, Allerup, Peter, Larsen, Jane, Torre, André 2010. Med spredning som muligt svar. København: Danmarks Pædagogiske Universitetsskole, Aarhus Universitet.

K o r e i n i k, Kadri 2011. Language ideologies in the contemporary Estonian public discourse: With a focus on South Estonian. (Dissertationes Sociologicae Universitatis Tartuensis 5.) Tartu: Tartu University Press. 
L i n d e m a n n, Kristina 2011. The Labour Market Success of Ethnic Groups: the Reality and Perceived Perspectives. - Towards a Normal Stratification Order. Actual and Perceived Stratification in Post-Socialist Estonia. Toim E. Saar. Frankfurt am Main: Peter Lang, lk 481-499.

MISA 2009 = Võrdsest kohtlemisest teadlikkuse tõstmise kampaania eeluuring. Fookusgrupiuuringu aruanne. Läbiviija: Saar Poll. Tellija: Integratsiooni ja Migratsiooni Sihtasutus. Käsikirjaline dokument Integratsiooni ja Migratsiooni Sihtasutuses.

P e d e r s e n, Michael Svendsen 2002. Hold på briller, professionalisme og arbejde. - Sprogforum, nr 23, lk 4-6.

P h i 1 li p s o n, Robert 2001. Global English and local language policies. What Denmark needs. - Language Problems and Language Planning, kd 25, nr 1, lk 1-24.

P o o l, Raili, Te n je s, Silvi 2011. Konverents „Emakeel ja teised keeled VII”. Keel ja Kirjandus, nr 5, lk 392-394.

$\mathrm{R}$ a m a $\mathrm{n}$ ath a n, Vaidehi 2005. Rethinking language planning and policy from the ground up: Refashioning institutional realities and human lives. - Current Issues in Language Planning, kd 6, nr 2, lk 89-101.

R i c e n t o, Thomas (toim) 2005. An Introduction to Language Policy: Theory and Method. Oxford: Blackwell Publishing.

$\mathrm{S} \mathrm{ch}$ if f m a n, Harold 1996. Linguistic Culture and Language Policy. Oxford-New York: Routledge.

S i i n e r, Maarja 2010. Hangovers of globalization. A case-study of laissez-faire language policy in Denmark. - Language Problems and Language Planning, kd 34, nr 1, lk 43-62.

S i i n e r, Maarja 2012. Towards a More Flexible Language Policy: An Analysis of Language Policy Design in Denmark and Estonia. Doktoritöö käsikiri. Tartu Ülikool, ajakirjanduse ja kommunikatsiooni instituut.

Si i ner, Maarja, Viha le m m, Triin, Dja ckova, Svetlana, R a moniene, Meilute 2011. Keelepoliitika rakendamine ja selle seos venekeelse elanikkonna lõimumisega. - Eesti Inimarengu Aruanne 2010/2011. Tallinn: AS Eesti Ajalehed, lk 122-129.

Spolsky, Bernard 2004. Language Policy. Cambridge: Cambridge University Press.

Z i n k e r n a g e 1, Peter 1992. Virjkelighed. København: Munksgaard.

T o ll e f s o n, James W. 2006. Critical theory in language policy. - An Introduction to Language Policy: Theory and Method. Toim T. Ricento. Oxford: Blackwell Publishing, lk 42-59.

V a n d e r A a, Jef, B l o m m a e r t, Jan 2011. Ethnographic monitoring: Hymes' unfinished business in educational research. - Working Papers in Urban Language and Literacies, nr 69.

V i h a l e m m, Triin, S i i n e r, Maarja 2011. Balti riikide lõimumis- ja keelepoliitika Euroopa Liidu kontekstis. - Eesti Inimarengu Aruanne 2010/2011. Tallinn: AS Eesti Ajalehed, lk 118-121.

Vih a le m m, Triin, Si in e r, Maarja, M a s s o, Anu 2011. Sissejuhatus: keeleoskus inimarengu tegurina. - Eesti Inimarengu Aruanne 2010/2011. Tallinn: AS Eesti Ajalehed, lk 116-117. 


\section{Sustainable Language Policy: Why and How?}

Keywords: language policy, language users, actors, integration, Estonian as L2

The article takes stock of the sustainability of the present language policy in Estonia, asking how capable the ongoing language management is in face of the future challenges of a modern nation state in a globalizing world. The authors offer a critical analysis of the existing technocratic understanding of language policy as a top-down mechanism where political aims are transferred unchanged from decision makers through implementers to passive receivers (language users). Inspired by the writings of some critical sociolinguists and ethnolinguists, the authors propose an understanding of the language policy as a designing tool of the language environment, which is based on the rationale of the language users' everyday practices, including their options for social mobility, economic well-being, political participation, access to education and for becoming self-supportive. In an ethnographic approach to language policy, the possibilities for local appropriations in policy implementation and for solving local problems through local initiatives are seen as „free spaces”. Comparing the language political tools used for integrating the ethno-linguistic minority population in the labour markets of Denmark and Estonia, the authors conclude that Estonia's language political design is relatively top-down and symbolic as in Estonia, less free space is left for solving language problems locally, or for meeting the contextual needs of language users than in Denmark. The Danish language political design is more flexible (despite being even more demanding in regard to Danish language acquisition) as there the policy-making is left to the actors of lower levels (local government, organizations) and thereby the local contextual solutions are not perceived as socially unjust. If, however, the role of state is central in both defining language problems and finding solutions, it is difficult to find ad hoc solutions to local or contextual language problems. Considering the complexity of language policy as an object of study, the authors call for a more interdisciplinary approach to language political issues, with an involvement of specialists from politics, social sciences, economy, law and linguistics.

Maarja Siiner (b. 1973), PhD, Advisor on Labour Market and Integration, Department for Employment at the City Government of Copenhagen, maarja@siiner.eu

Triin Vihalemm (b. 1968), PhD, Professsor of Communication Studies, Institute of Journalism and Communication, University of Tartu,triin.vihalemm@ut.ee 